\title{
THE DETERMINANTS OF CORPORATE CASH HOLDINGS: DOES COUNTRY'S LEGAL REGIME MATTER? EVIDENCE FROM BRIC AND TURKEY
}

\author{
DOI: 10.17261/Pressacademia.2019.1150 \\ JEFA- V.6-ISS.4-2019(2)-p.192-205
}

Guler Aras ${ }^{1}$, Ozlem Kutlu Furtuna ${ }^{2}$, Nuray Tezcan ${ }^{3}$

${ }^{1}$ Yildiz Technical University, Center for Finance Governance and Sustainability (CFGS), Istanbul, Turkey. dr.guler.aras@gmail.com, ORCID ID: 0000-0002-9438-7191

${ }^{2}$ Yildiz Technical University, Center for Finance Governance and Sustainability (CFGS), Istanbul, Turkey. ozzlemkutlu@yahoo.co.uk, ORCID ID: 0000-0001-8230-200X

${ }^{3}$ Halic University, Business Informatics Department, Istanbul, Turkey. nuraytezcan@hotmail.com, ORCID ID: 0000-0002-3184-7330

Date Received: November 12, 2019

Date Accepted: December 14, 2019

To cite this document

Aras, G., Furtuna, O.K., Tezcan, N., (2019). The determinants of corporate cash holdings: Does country's legal regime matter? Evidence from BRIC and Turkey. Journal of Economics, Finance and Accounting (JEFA), V.6(4), p.192-205.

Permemant link to this document: $\mathrm{http} / / /$ doi.org/10.17261/Pressacademia.2019.1150

Copyright: Published by PressAcademia and limited licenced re-use rights only.

\begin{abstract}
Purpose - This study aims to fill the gap for BRIC countries and Turkey by looking into the determinants of cash holding across different firm sizes and industries with a perspective on country's legal regime.

Methodology- The sample contains 5.840 firm-year observations across these countries for the period 2005-2014. Capital expenditure, growth opportunities, liquid asset substitutions, leverage, profitability, firm size and GDP per capita- as a measure of the economic development- have been taken to explore the determinants of corporate cash holdings. In order to see whether country's legal regime matter; the shareholder protection has also been discussed as a determinant of corporate cash holding. Several models have been implemented for each of the cash holding measures, and all of them are estimated by panel data regressions with fixed effects.

Findings- The results gave strong evidence that potential investment and growth opportunities, liquid asset substitution and firm size significantly affect the cash holdings decisions of non-financial firms and that are in conformity with the existing literature on the determinants of corporate cash holdings. Besides this, findings provide support for the notion that related firms is under financial constraint and tend to hold more cash as a result of the precautionary motive for cash.

Conclusion- These multicounty results, together with the view of common and civil-law differentiation, suggest that country characteristics strongly influence the determinants of cash holding. Countries which have poor corporate governance hold cash at higher levels compared to countries that have good corporate governance.
\end{abstract}

Keywords: Corporate cash holding, liquidity, financial constraint, corporate governance, BRIC, Turkey, panel data. JEL Codes: C23, G30, G38

\section{INTRODUCTION}

Cash and cash equivalent are considered to be one of the most important components of the current assets of the firm and are also called the life line of corporate financial management. Ever since Opler et al. (1999) first investigated the effects of various financial variables on the level of cash holdings for U.S. firms, there has been growing attention in explaining why firms hold cash. Initial studies by Jensen and Meckling (1976), Myers (1984), Jensen (1986), and Myers and Majluf (1984) have debated the potential benefits and costs of holding cash.

The determinants of corporate cash holdings have traditionally been studied from the perspective of three dominant cash holding theories: Kraus and Litzenberger's trade-off theory (1973), Myers and Majluf's pecking order / financial hierarchy theory (1984) and Jensen and Meckling's agency theory (1976). According to Kraus and Litzenberger's (1973) trade-off theory, cash holdings are the result of a trade-off between the benefits and costs associated with holding cash, the marginal benefit and marginal cost of debt has to be considered. Some of the benefits are that cash enables firms to take and continue 
the projects without raising external funds that are at high transaction costs, to pay dividends and not to decrease it under cash shortage. The majority of the papers confirmed that the tradeoff theory exists and researchers have found evidence that firms in countries with greater investor protection and better capital markets hold less cash (Opler et al. (1999) and Kim et al. (1998) since when firms need cash for financing the projects that are profitable they usually go to the capital market for it.

Myers and Majluf (1984)'s pecking order theory, or financing hierarchy model, challenges the trade-off theory by rejecting the existence of an optimal level of cash holdings. The first preference of the firms to finance their investments is given to retained earnings, and then debt and finally at the end they prefer for equity share due to the new equities are highly costly to issue. Jensen and Meckling's (1976) agency theory states that cash holdings are the result of management entrenchment. If investment opportunities are scarce and the firms is constrained, it will prefer holding cash in the company instead of paying it out to shareholders. Moreover, in free cash flow theory by Jensen (1986) managers want to hold more cash so as to exercise more power in decisions regarding investments. With high cash levels by firms the need to take external finance and increase in free cash flow is associated with increase in agency conflicts that is between management and shareholders.

Among the theories, the motives of holding corporate cash have to be clarified. The precautionary motive states that firms hold cash for the future uncertainty. The transaction motives underlying that cash holding can be used as a tool for lowering the transaction cost. Baumol (1952). The tax motive arguing firms hold cash for avoiding double taxation.

The remainder of the study is organized as follows. After the literature review part, the following section represents data selection and methodology. Findings have been discussed in the fourth section. Additionally, in order to explore whether country's legal regime matters in determination of corporate cash holdings for the related countries, further data analysis has been utilized. Finally, concluding remarks are revealed in the last section.

\section{LITERATURE REVIEW}

Several empirical studies carried out relating to cash holdings are more focused on the determinants of corporate cash holdings. For instance, Opler et al. (1999) are among the pioneer researchers who investigated the determinants of cash holdings. They study the determinants and implications of cash holdings amongst publicly traded US firms from 1971 to 1994. They state that stronger growth opportunities, higher business risks, and of smaller held more cash than firms which displayed these attributes to lesser degrees.

Ali and Yousaf (2013) demonstrate the determinants of the cash holdings in 876 non-financial German firms during the period 2000-2010. They found the most significant economic impact was for the presences of the substitutes for cash in the balance sheet of the corporation under current assets. Almeida et al. (2004) investigate the extent to which the cash flow sensitivity of cash provides an empirically useful measure of financial constraint for the all US manufacturing firms during the years 1971 to 2000 . They demonstrate that financially unconstrained firms should not increase their propensity to retain cash following macroeconomic shocks, while constrained firms should.

As for the developing countries, the literature for the topic is scarce which contradicts to the significance of the topic due to the growing economic activities of BRIC and Turkey. Firms in these countries have considerably increased their cash holdings over the past decades. A growing literature has emerged to investigate its determinants and its consequences for firm behavior. This study aims to fill that gap for BRIC countries and Turkey by looking into the determinants of cash holding in nonfinancial firms of BRIC(T) across different firm sizes and industries with a perspective on country's legal regime.

For BRIC firms, Al-Najjar (2013) examines the effect of capital structure and dividend policy on cash holdings in these countries and compare our results with a control sample from the US and the UK. For the period 2002-2008, he provides evidence that capital structure, dividend policy, and firm size are important factors in determining cash holdings. He also state show firms operating in countries with low shareholder protection hold more cash

Amess et al. 2015 argue that China represents an interesting context for investigating corporate cash holdings because government agencies retain a controlling or significant ownership stake in Chinese firms. Chen et al. 2012 investigate all nonfinancial firms listed on the Shanghai and Shenzhen stock exchanges from 2000 to 2008. In 2005, the split share structure reform commenced in China and they report that the cash holding ratio significantly decrease. Moreover, Ameer (2014) investigates the investment ratios of 519 non-financial listed firms in six Asian countries (India, S.Korea, Indonesia, Malaysia, Pakistan and Thailand) over the period of 1991-2004. He states that investment-cash flow sensitivities vary across firms in the sample countries. Hall et al. 2014 investigate the determinants of cash holding at privately held and publicly held firms for 20 emerging between the years 2001 to 2010. Privately held emerging market firms tend to hold more cash than public firms. 
A recent study for Turkish Business Groups was done by Cetenak and Vural (2015). They investigate investment-cash flow sensitivity of the Borsa Istanbul manufacturing firms by considering affiliation with 164 business groups during 2004 to 2012 . They state an insignificant investment-cash flow relationship for the firms affiliated with a major business groups and firms which have more than $\% 15$ foreign shareholders. However, they report strong investment-cash flow sensitivity for the small business groups affiliated firms and non-affiliated independent firms. Uyar and Kuzey (2014) analyze the factors that might explain the level of corporate cash holdings in a broad sample of Turkish-listed nonfinancial firms over the period 1997 to 2011. The results reveal that cash flow and growth opportunities have positive and significant impact on the cash level.

More recently, a number of papers have documented evidence that corporate governance at both country and firm levels could potentially influence corporate cash holdings in U.S. and international firms. However, the conclusions from this strand of research are relatively mixed. Aras et al. 2015 investigate BRIC firms' governance practices on the impact of financial structures in terms of financial profitability and financial leverage. Findings provide support for the notion that board independence, representation of women on the board, duality, and the number of board meetings are key factors in determining corporate governance efficiency and play important roles in enhancing firm financial structure in BRICK firms. She also states that the common and civil-law differentiation strongly influence the aspects of governance practices while predicting firm financial structure. Lee and Lee (2009) state that for 1.061 firms initiated in five ASEAN countries (Malaysia, Philippines, Indonesia, Singapore and Thailand) with higher expected managerial entrenchment, those with higher proportion of outside director on the board and smaller board size have lower cash holdings

This paper aims to investigate the determinants that affect the level of cash holdings. Cash and cash equivalent is a significant policy matter in the field of modern corporate finance that is why this research work is intended to provide solution to the corporate managers regarding accessing cash and liquid assets requirement. Furthermore, these multicounty results, together with the view of common and civil-law differentiation, suggest that country characteristics strongly influence the determinants of cash holding.

\section{DATA AND METHODOLOGY}

The sample for this empirical analysis is gathered from the Bloomberg Professional Database for BRICs and Turkish firms for the period 2005-14. For Brazil, a sample composed of 670 nonfinancial firms with shares traded on the Brazil BOVESPA Stock Index. For Russia, 50 nonfinancial firms listed on the Eastern Europe MICEX Main Russian Index. For India, a sample of 126 nonfinancial firms traded on the Bombay Stock Exchange. For China, 134 nonfinancial firms listed on the Shanghai Stock Exchange. Finally, in Turkey, 207 nonfinancial firms listed on Borsa Istanbul. The exclusion of financial institutions is due to the influence of statutory capital requirements and other governmental regulatory requirements on their cash holdings.

For alleviating the problems of outliers, all financial variables are winsorized at the 1st and the 99th percentile levels. As a result, the final sample includes 5840 yearly firm observations between 2005 and 2014 for 584 listed companies. The software package used for the analyses is Stata 11.

\subsection{Variables}

There is no preference in the finance literature, about the best theory that can explain the determinants of cash holdings and thus there is no optimal set of factors that determine the decision to hoard cash. One of the aim of this study is to empirically test which variables determine cash holdings for the firms across BRIC and Turkey.

\subsubsection{The Dependent Variable}

The first dependent variable (CASH1) is the corporate cash holdings ratio. This ratio is the expression of the balance sheet's cash and cash equivalents account divided by the balance sheet's total assets account (Kusnadi 2011; Najjar 2013; Ho et al.2014; Borhanuddin and Ching 2011; Chen 2008; Loncan and Calderia 2013; Ali 2013, Uyar and Kuzey 2014; Ali and Yousaf 2013; Anagnostopoulou 2013; Hall 2014; Najjar 2013).

Nonetheless, the literature is divided on the calculation of this ratio. Others like Opler et al. (1999); Dittmar et al. (2003); Pinkowitz et al. (2013); Ramirez and Tadesse (2009); Kuan et al. 2012; Harford et al. (2008); Masood and Shad (2014); Harford et al.(2006), Pinkowitz et al. (2006), Kusnadi (2011), Chen (2008), Ammann et al. (2010) and Kuan et al. (2011); Belkhir et al. (2014). Borhanuddin and Ching (2011); Gill and Shah (2012); Lee and Lee (2009); Chen et al. (2014) argue that it should be divided by net assets defined as total assets minus cash and cash equivalents, since cash is not an asset in place and does not generate profits. Net assets are computed as total assets less cash and cash equivalents. Following this argument, the second determinant of the cash holding (CASH2) is used as the dependent variable in testing for robustness. Therefore, that variable makes a good dependent variable for robustness testing, since the divisor is scaled down considerably and the differences between observations' cash holdings more apparent. 
Other measurement of cash holdings in literature has also given. The measurement of cash holding is expressed by log of cash by Anagnostopoulou (2013); Kusnadi (2011) and earnings before interests, taxes, depreciation and amortization, less interests, taxes and dividends; this is then divided by total assets and expressed as free cash flow by Chen et al. (2009); Chen et al. (2015a). According to Belkhir et al. (2014); cash as a liquid investment necessary to support the working capital needs of the firm, which is closely related to its sales. He used the ratio of cash to sales, computed as the log of cash and cash equivalents to total sales as cash holding proxy. Belkhir et al. (2014) state excess cash by calculating the residual value from the equation. Furthermore, cash flow sensitivity has also been studied by Almeida et al. (2004); Ameer (2014); Attig et al. (2013).

Though not tabulated, two alternative methods is constructed to measure cash holdings in this study. First, direct measure of cash (CASH1) is calculated. Second, cash holdings using the ratio of cash and marketable securities to net assets computed as total assets minus cash and marketable securities (CASH2) similar to fundamental study of Opler et al. (1999). Later, given that industry classification is a significant factor in the determination of cash holdings, following the Subranimian et al. (2011) methodology an industry-adjusted measure of the firm's cash to sales ratio (ADJCASH) is created. Detailed information has been stated while discussing the industry affect.

\subsubsection{The Independent Variables- Determinants of Cash Holding}

This subsection handle only studies on the determinants of cash holdings.

The first determinant of cash holding represents the capital expenditures ratio (CAPEX) and serves as a proxy for controlling the potential investment opportunities. The trade-off theory suggests a positive relationship between cash holdings and capital expenditures. Companies that have high capital expenditures will need to hold more cash in order to keep the transaction costs associated with external capital low. On the other hand, the pecking order theory states a negative relationship between cash holdings and capital expenditures. Firms that have high capital expenditures will have their cash holdings drained and thus have lower cash holdings as capital expenditures go up. This view is supported by studies such as Bates et al. (2009). In this study, CAPEX is measured as the capital expenditures divided by assets. The same formula is used in Ramirez and Tadesse (2009); Opler et al. (1999) and Dittmar et al. (2003); Verduyn (2013); Borhanuddin and Ching (2011); Subramaniam et al. (2011), Daher (2010) and Anjum and Malik (2013) propose another formula to measure investment opportunities; the yearly sales growth rate.

The second variable captures the future growth opportunities, has been measured as the market-to-book ratio (MB). In most previous empirical research (Ogundipe et al. 2012, Koshio and de Sales Cia 2003, Ferreira and Vilela 2004, Ali and Yousaf 2013, Guney and Ozkan 2006, Luo 2011).

Trade-off theory suggests a negative relationship between the amount of liquid asset substituts and cash holding. For the liquidity of the firms consistent with the studies of Kim et al. (1998), Harford (1999), Opler et al. (1999) and Dittmar et al. (2003), Net Working Capital divided by net assets (LIQ) is used. This variable captures and controls for the additional liquid assets that are held by the firm. It is equal to or a substitute for cash and equivalents (Lee and Lee 2009; Subramaniam et al. 2011, Al-Najjar 2013, Verduyn 2013, Ali and Yousaf 2013, Kim Mauer and Sherman 1998, Hall et al. 2014).

The trade-off theory states that firms will hold more cash as leverage increases in order to reduce the probability of financial distress. Moreover, the pecking order theory states that debt levels are directly related to investment and retained earnings. Therefore, the pecking order theory provides a negative relationship between leverage and cash holdings. Prior studies state that cash levels decrease with more debt. Accordingly, firms with more liquid assets can covert these assets to cash and in turn hold lower levels of cash. Following the studies; Al-Najjar and Belghitar (2011); Ozkan and Ozkan (2006), Verduyn (2013); Kusnadi (2011); Lee and Lee (2009), Borhanuddin and Ching (2011); Gill and Shah 2012; Ali and Yousaf (2013) total debt over total assets (LEV) is used. Moreover, Al-Najjar (2013) and Verduyn (2013) use the short-term debt between year $t$ and $t-1$ divided by total assets at the end of year.

The trade-off theory suggests that dividend paying firms can raise funds by cutting dividend payments, while firms that do not pay any dividends can only raise funds through the capital markets. This makes sense to the argument that dividend paying companies hold less cash than their counterparts. Therefore, dividend payouts (DIV) are also frequently used as a financial determinant of cash holding (Al-Najjar 2013, Verduyn 2013, Anagnostopoulou 2013, Gill and Shah 2012, Kuan et al. 2012, Masood and Shah 2014). Firms cannot pay dividends when they are in need of cash. It acts as a substitute of cash for the firms.

The control variables included in the study which explain variation in the cash holdings of firms are consistent with Kusnadi (2011), Harford et al. (2008), Opler et al. (1999), Chen (2008), Kuan et al. (2011), Ammann et al. (2011). Profitability as the 
return on asset $(R O A)$ is used as the first firm specific control variables similar with the Verduyn (2013); Hall et al. (2014). Anagnostopoulou (2013).

The trade-off theory proposes a negative relationship between cash holdings and company size. The Miller and Orr (1966) model state that there are economies of scale in cash management. This means that larger companies would have less need to hold a buffer of cash and thus lower levels of cash holdings. On the other hand, the pecking order theory states that larger firms have been more successful and should have more cash. This would lead to a positive relationship between cash holdings and company size. Therefore, another firm specific variable is natural logarithm of total assets (in millions of US dollars) as a proxy for size measure is used (SIZE). This determinant of cash holding is also used in similar with the studies of Al-Najjar (2013); Verduyn (2013); Kusnadi (2011); Ali and Yousaf (2013); Gill and Shah 2012; Lee and Lee 2009; Subramaniam et al. (2011).

For the country specific variables; GDP per capita (GDP) is used as a measure of the economic development similar with the Acharya et al. (2011), Pinkowitz et al. (2006) and Chen et al. (2015b). Brazil has the highest average GDP per capita over the sample period and India has the lowest.

Table 1 provides the dependent, explanatory, and control variables utilized together with their abbreviations and definitions in light of the discussion in the literature review section.

Table 1: Abbreviations and Definitions of Variables

\begin{tabular}{|c|c|c|}
\hline \begin{tabular}{|l|} 
Variable Name \\
\end{tabular} & Definition & Abbreviation \\
\hline Cash Holdings & Cash / Total Assets & CASH1 \\
\hline \begin{tabular}{|l|} 
Net Cash Holdings \\
\end{tabular} & Cash \& Cash Equivalents / Net Assets & CASH2 \\
\hline Imputed Cash & $($ Imputed Cash $)=\sum_{n=1}^{n}\left(\right.$ Asset $\left._{i} * \frac{\text { Cash }}{A s s e t}\right)$ industry & \\
\hline Industry Adjusted Cash & (Cash-ImputedCash)/Asset & $A D J C A S H$ \\
\hline \multicolumn{3}{|l|}{ Independent Variables } \\
\hline Capex & Capital expenditure divided by assets & CAPEX \\
\hline $\begin{array}{l}\text { Growth/Investment } \\
\text { Oppurtunity }\end{array}$ & $\begin{array}{l}\text { Market value of the firm (book value of asset less the } \\
\text { book value of the equity, plus the market value of the } \\
\text { equity), divided by book value of the assets }\end{array}$ & $M B$ \\
\hline Liquid Asset & NWC/Total Asset & $L I Q$ \\
\hline Net Working Capital & $\begin{array}{l}\text { (Working capital- cash and short-term investments)/ } \\
\text { total assets }\end{array}$ & \\
\hline \begin{tabular}{|l|} 
Leverage \\
\end{tabular} & Total debt over total assets & LEV \\
\hline Dividend Yield & $\begin{array}{l}\text { Annual dividends per share divided by the } \\
\text { price per share }\end{array}$ & $D I V$ \\
\hline Profitability & Return on Asset & $R O A$ \\
\hline Size & Natural log of Asset & $S I Z E$ \\
\hline \begin{tabular}{|l|} 
Gross Domestic \\
Product per capita
\end{tabular} & Proxy for countries' economic development & $G D P$ \\
\hline
\end{tabular}

\subsection{Industry Effect}

This study has investigated firms from eighteen industries i.e. materials, utilities, transportation, consumer durables, media, pharmaceuticals, household products listed in Bloomberg Professional Database. Each industry has its own characteristic. Certain industries' earnings are highly volatile and are of high risk. This will affect the cash holdings decision indirectly. Simply adding industry dummies to the regression explaining cash holdings is not appropriate for the purpose of the study. This paper follows the similar methodology of Berger and Ofek (1995), Subramaniam et al. (2011) and Brisker et al. (2013) to construct the main dependent variable-industry-adjusted cash holdings.

For determining (ADJCASH); first, the median ratio of cash over total assets (CASH/TA) for each industry is calculated. Then, imputed cash holdings Imputed Cash; as the product of the firms' industry median (CASH2) and its net asset value is defined. Lastly, adding up ImputedCash for each segment of a diversified firm gives us the firm-level ImputedCash. Third dependent variable of cash holdings then generated and it is the difference between the actual cash holdings of the firm and the ImputedCash, scaled by total assets of the firm. This variable is stated as ADJCASH (Cash-ImputedCash)/TA and effectively 
controls for any industry effects in the regressions. Positive ADJCASH indicates that the firms hold more cash than their counterparts and negative ADJCASH indicates that firms hold less cash compared with counterparts. The methodology of using the $A D J C A S H$

Using the same methodology of Subramanian (2011) the possible endogeneity problem is concerned. Unadjusted Cash to Total Assets along with the primary industry dummy variable as a control variable in the regressions to control for the industry affiliation of the sample. The empirical results indicate that the inferences are all unchanged.

Table 2 represents the corporate cash holding statistics across industries by industry between the years 2005-2014. The industry is defined according Bloomberg Professional Database Industry Codes. Panel A shows the bottom 5 industries with the least cash holdings and Panel B shows the top 5 industries with the most cash holdings. While CASH 2 variable makes a good dependent variable for robustness testing, it is used.

\section{Table 2: Corporate Cash Holdings by Industry}

\section{Panel A: Bottom 5 Industries}

\begin{tabular}{llccc} 
& Industry description & Median & Mean & Std.Dev. \\
\cline { 2 - 5 } 2520 & Consumer Durables \& Apparel & .0586 & .1091 & .1513 \\
3020 & Food, Beverage \& Tobacco & .0706 & .1331 & .1746 \\
5510 & Utilities & .0894 & .1034 & .0766 \\
1510 & Materials & .0939 & .1404 & .1554 \\
2030 & Transportation & .0996 & .1472 & .1347
\end{tabular}

Panel B: Top 5 industries

\begin{tabular}{llccc} 
& Industry description & Median & Mean & Std.Dev. \\
\cline { 2 - 5 } 4510 & Software \& Services & .2314 & .2971 & .2501 \\
4520 & Technology Hardware \& Equipment & .2299 & .3010 & .2580 \\
3510 & Health Care Equipment \& Services & .1822 & .2068 & .1399 \\
3030 & Household \& Personal Products & .1675 & .2178 & .1693 \\
3520 & Pharmaceuticals, Biotechnology \& Life Sciences & .1653 & .2117 & .1866
\end{tabular}

Top five industries hold as much as ten times more cash as a percentage of total assets than the bottom five industries. For instance; Consumer Durables \& Apparel industry with the lowest cash holdings, has a median (mean) of $5.86 \%$ (10.91\%), whereas software \&services, the industry with the highest cash holdings, has a median (mean) of $23.14 \%(29.71 \%)$.

The large industry variation for cash holdings indicates that controlling for the industry effects is crucial for the purpose of the analysis.

Table 3: Corporate Cash Holdings by Country

\begin{tabular}{lcccccc} 
Country/variables & Mean & Median & Std Dev & Min & Max & N \\
\hline Brazil & & & & & & \\
CASH1 & .0864 & .0608 & .0876 & .0000 & .7234 & 641 \\
CASH2 & .1823 & .1390 & .1558 & .0001 & .9587 & 632 \\
Russia & & & & & & \\
CASH1 & .0605 & .0434 & .0602 & .0004 & .3373 & 485 \\
CASH2 & .1084 & .0659 & .1264 & .0006 & .8285 & 481 \\
India & & & & & & \\
CASH1 & .0402 & .0217 & .0711 & .0000 & .7935 & 1209
\end{tabular}




$\begin{array}{lllllll}\text { CASH2 } & .1662 & .1047 & .1815 & .0002 & .9622 & 1151 \\ \text { China } & & & & & & \\ \text { CASH1 } & .1897 & .1476 & .1514 & 0.0003 & .8781 & 1301 \\ \text { CASH2 } & .2282 & .1670 & .1965 & .0003 & .9839 & 1228 \\ \text { Turkey } & & & & & & \\ \text { CASH1 } & .0857 & .0510 & .0980 & .0000 & .5912 & 1985 \\ \text { CASH2 } & .1118 & .0564 & .1469 & .0000 & .9715 & 1961\end{array}$

Summary statistics show the mean, median, standard deviation, minimum and maximum values of the variables and provide a general overview of the characteristics of the data. The mean cash ratio for Chinese firms has the highest cash levels. These statistics are very close to the US firms' mean cash ratio of $17 \%$ as reported by Opler et al (1999) and the European firms' mean cash ratio of $14.8 \%$ as reported by Ferreira and Vilela (2004).

Uyar and Kuzey (2014) also report that on average, Turkish-listed nonfinancial firms hold $9.1 \%$ of their total assets as cash and cash equivalents over the period 1997 to 2011. Moreover, Chen et al. (2012) investigate all nonfinancial firms listed on the Shanghai and Shenzhen Stock Exchanges from 2000 to 2008. They state the mean (median) pooled sample ratio of cash to all noncash assets is $23.4 \%(15.7 \%)$. In 2005 , the split share structure reform commenced in China and they report that the cash holding ratio significantly decrease. Results are similar with the Ramiraz and Tadesse (2009) findings. They state the average cash holdings in Brazil, Russia, India and China are $9 \%, 7 \%, 6 \%$, and $18 \%$, respectively.

The majority of the papers confirmed that the tradeoff theory exists and researchers have found evidence that firms in countries with greater investor protection and better capital markets hold less cash (Opler et al. (1999) and Kim et al. (1998). This table states that firms located in common law (India) has the lowest cash ratio rather than the firms located in civil-law countries (Brazil, Russia, China and Turkey).

\subsection{Methodology}

As also emphasized in the prior subsections relating to methodological procedures and model specifications, major findings of this study has been evaluated by the use of panel data analysis due to its superiority over cross sectional analysis performed in the study.

All the models applied are determined to be significant with respect to F-statistic and Wald statistic, which are significant at $\mathrm{p}<0.001$. Wald-statistic, which is the chi-squared version of the F-test, is the F-statistic after a simple transformation applicable to any estimator that is consistent and asymptotically normal (Wooldridge 2009).

The first panel data estimation model, which evaluates the first determinant of corporate cash holdings in terms of CASH1 can be demonstrated as in Equation 1.

The functional forms of the models are as follows:

CASH1it $=\beta 0+\beta 1 C A P E X i t+\beta 2 M B i t+\beta 3 L I Q i t+\beta 4 L E V i t+\beta 5 D I V i t+\beta 6 R O A i t+\beta 7 S I Z E i t+\beta 8 G D P+\varepsilon_{i t}$

The second panel data estimation model, which evaluates the second determinant of corporate cash holdings in terms of CASH2 can be demonstrated as in Equation 2.

$C A S H 2 i t=\beta 0+\beta 1 C A P E X i t+\beta 2 M B i t+\beta 3 L I Q i t+\beta 4 L E V i t+\beta 5 D I V i t+\beta 6 R O y i t+\beta 7 S I Z E i t+\beta 8 G D P+\varepsilon_{i t}$

The third panel data estimation model, which evaluates the final determinant of corporate cash holdings in terms of ADJCASH can be demonstrated as in Equation 3. This model takes a closer look at the differences of the determinants of cash holdings in the various sectors in BRICT firms.

$A D J C A S H i t=\beta 0+\beta 1 C A P E X i t+\beta 2 M B i t+\beta 3 L I Q i t+\beta 4 L E V i t+\beta 5 D I V i t+\beta 6 R O A i t+\beta 7 S I Z E i t+\beta 8 G D P+\varepsilon_{i t}$

where CASH1it is the cash ratio measured by cash and cash equivalents to total assets ratio in year $t$ for firm $i$; CASH2it is the cash ratio measured by cash and cash equivalents to net assets ratio in year $t$ for firm i; ADJCASHit is the product of the firms' industry median and its net asset value in year $t$ for firm $i$; CAPEXit is the capital expenditure divided by assets in year $t$ for firm $i$; MBit is the market value of the firm divided by book value of the assets in year $t$ for firm $i$; LIQit is the liquidity ratio measured by the net working capital divided by total asset in year $t$ for firm $i$; LEVit is the leverage ratio, measured by total debt to total assets in year $t$ for firm $i$; DIVit is the dividend payout ratio measured by dividends per share divided by earnings 
per share in year $t$ for firm $i$; ROAit is the return on assets ratio measured by net income divided by assets in year $t$ for firm $i$; SIZEit is the natural logarithm of total assets in year $t$ for firm $i$; GDP is the proxy for countries' economic development in year $t$ for country and $\varepsilon$ is the error term.

\section{FINDINGS AND DISCUSSIONS}

Based on the tradeoff theory, the association between capital expenditures and cash should be negative, since firms with more and larger capital expenditure tend to hold less cash (Dittmar et al. 2013; Guney and Ozkan 2006; Afza and Adnan 2007; Chen et al. 2015b,Anagnostopoulou 2013) whereas Opler et al. (1999) found just the opposite evidence. This study fails to find any relationship in all models. The regression coefficient for capital expenditures is seen as negative in Table 4. This provides limited empirical support to the proposition that firms with more capital expenditure tend to hold less cash. Chen (2008) also finds any relationship between capital expenditures and cash holding for S\&P 1.500 firms.

The existence of growth opportunities in corporations is a significant factor that positively affects cash levels, as has been shown in various empirical studies Kim et al. (1998); Opler et al. (1999); Ferreira and Vilela (2004); and Ozkan and Ozkan (2002); Ali and Yousaf (2013); Chen et al. (2015b). Although this study states limited empirical support that firms with growth opportunities negatively affects cash levels, only for the second model a significant negative impact is found. This represents that firms in BRICT with low growth opportunities hold less cash to avail opportunities available.

Firms with highly liquid assets will hold less cash because those assets can easily be converted in case of a cash shortage. That is why the trade-off theory suggests a negative relationship between cash holdings and the amount of liquid asset substitutes. The ratio of net working capital minus cash to total assets is used as a proxy for liquid asset substitutes and a negative relationship is expected because liquid assets can be seen as a substitute for cash in the event of a cash shortage (Afza and Adnan 2007; Megginson and Wei (2010); Gill and Shah 2012; Ferreira and Vilela, 2004; Ali and Yousaf 2013; Belkhir et al. 2014; Chen et al. 2015b). The pecking order theory and agency theory do not propose any relationship between cash holdings and liquid asset substitutes. Interestingly, for all the models, firms with higher liquid assets substitutes hold high cash is found.

The leverage ratio also affects a firm's cash holdings. Previous research in developed and emerging countries (Opler et al. 1999, Ozkan and Ozkan 2002, Al-Najjar and Belghitar 2011) have found there to be a negative relationship between cash holdings and leverage. This negative relationship is also supported by free cash flow theory but the main reason is because high leverage firms are subject to monitoring by capital markets preventing superior managerial control (Ali and Yousaf 2013; Rizwan and Javed 2011). On the other hand, although the trade-off, pecking order and free cash flow theory suggests a negative relationship, this study fails to find any impact of leverage on corporate cash holding for all the models similar with the results of Chen (2008). The insignificant relationship implies that leverage cannot act as a substitute of cash holdings for BRICT firms and exert an impact on the firm's cash holding decisions in all models.

Research results are divided on the subject of dividend payments and cash holding. Based on the tradeoff theory, the association between dividend payments and cash should be negative, since dividend paying firms can trade off the costs of holding cash by reducing dividend payments (Opler et al. 1999; Al-Najjar 2013). On the other hand, Ozkan and Ozkan 2004) provide a positive relationship for UK companies. For the first model, firms with pay dividends hold less cash is found. The other models fails to find any significant relationship between dividend payment and cash holding.

Any significant relationship is found between firm profitability and cash holding for all models. Anagnostopoulou (2013) evidences positive coefficients for profitability and cash holding and he could further indicate that whenever the opportunity arises in terms of profitability and internally generated cash flows, firms take it as a chance to increase liquidity.

The pioneer studies of Baumol (1952), and Miller and Orr (1966) demonstrate that there are economies of scale associated with the cash levels required to confront the normal transactions of the firm, so that larger firms can keep lower cash holdings. However, smaller firms suffer more severe information asymmetries. They are more likely to suffer financial distress Rajan and Zingales (1995). Also, financial distress is associated with high fixed costs and these costs are proportionately greater for smaller firms (Ali and Yousaf 2013). This study finds a positive impact of firm size indicator on cash holdings which is most likely explained due to the fact that larger firms have been more successful and thus should have relatively more cash, consistent with the pecking order theory.

Country level control variable is GDP per capita is used following Pinkowitz et al. (2006). Acharya et al. (2011) also state that GDP per capita proxies for economic development and control for GDP per capita as developed and developing countries may have different investment opportunity sets. Pinkowitz et al. (2006) show that cash holdings are valued more in countries with higher financial development and higher economic development (Chen et al. 2015a). This study finds a negative 
relationship between GDP per capita and cash holding. However, Francis et al. (2013) state positive coefficients for (GDPPerCapita), because firms in countries with more developed financial markets have better investment opportunities.

Overall results indicate that only liquid asset form part of the determinants of cash holdings of related firms for all models. Some trade-off and pecking order theory expectations fail to find significant results for these firms.

Table 4: Fixed Effects Regression Model Results for the all Models

\begin{tabular}{|c|c|c|c|}
\hline & CASH1 & CASH2 & ADJCASH \\
\hline CAPEX & $\begin{array}{c}-0.0003 \\
(0.0003) \\
-0.0000\end{array}$ & $\begin{array}{c}-0.0005 \\
(0.0003) \\
-0.0000\end{array}$ & $\begin{array}{c}-0.0008 \\
(0.0006) \\
-0.0000\end{array}$ \\
\hline$M B$ & $(0.0000)$ & $(0.0000) * *$ & $(0.0000)$ \\
\hline$L I Q$ & $\begin{array}{l}0.1974 \\
(0.0223)^{* * *} \\
-0.0001\end{array}$ & $\begin{array}{l}0.5085 \\
(0.0423)^{* * *} \\
-0.0002\end{array}$ & $\begin{array}{l}0.4116 \\
(0.0686)^{* * *} \\
0.0000\end{array}$ \\
\hline LEV & $\begin{array}{l}(0.0002) \\
-0.0010\end{array}$ & $\begin{array}{l}(0.0003) \\
0.0001\end{array}$ & $\begin{array}{l}(0.0007) \\
-0.0016\end{array}$ \\
\hline DIV & $\begin{array}{l}(0.0005) * \\
0.0004\end{array}$ & $\begin{array}{l}(0.0008) \\
0.0006\end{array}$ & $\begin{array}{l}(0.0015) \\
0.0003\end{array}$ \\
\hline ROA & $\begin{array}{l}(0.0003) \\
0.0123\end{array}$ & $\begin{array}{l}(0.0005) \\
0.0192\end{array}$ & $\begin{array}{l}(0.0007) \\
0.0130\end{array}$ \\
\hline SIZE & $\begin{array}{l}(0.0039) * * * \\
-0.0000\end{array}$ & $\begin{array}{l}(0.0068)^{* * *} \\
-0.0000\end{array}$ & $\begin{aligned} & (0.0109) \\
- & 0.0000\end{aligned}$ \\
\hline GDP & $\begin{aligned} & (0.0000) \\
- & 0.0252\end{aligned}$ & $\begin{aligned} &(0.0000)^{* * *} \\
&-0.0143\end{aligned}$ & $\begin{aligned} &(0.0000)^{* * * *} \\
&-0.0015\end{aligned}$ \\
\hline constant & (0.0329) & $(0.0574)$ & (0.0949) \\
\hline obs & 3369 & 3275 & 2376 \\
\hline F test & $11.88 * * *$ & $23.35^{* * *}$ & $8.03 * * *$ \\
\hline Goodness of fit (R2) & 0.1322 & 0.2389 & 0.0729 \\
\hline \multicolumn{4}{|c|}{ legend ${ }^{*} p<0.10 ;{ }^{* *} p<0.05 ;{ }^{* *} p<0.01$} \\
\hline
\end{tabular}

\subsection{The Role of the Country's Legal Regime}

La Porta et al. (1998) argue that differences among countries in the structure of laws and their practices imply differences in stock market development and hence the protection of shareholders' rights. Moreover, governance has an impact on cash holdings. Following previous literature, which has shown corporate governance characteristics to be a significant contributor for cash ratios (Pinkowitz et al, 2006; Dittmar et al.2003; Anagnostopoulou 2013) the impact of differing corporate governance mechanisms on the cash ratios of common and civil law firms is further controlled.

One of the first study which takes into account the ownership data as the determinant of corporate cash holding belongs to Ozkan and Ozkan (2004). They provide evidence from a sample of 1,029 listed UK companies during the period 1984-1999 and find out that cash holdings are negatively impacted at low levels of ownership but that the impact is reversed at higher levels of ownership. Research conducted by Guney and Ozkan (2006), also shows that corporate governance is important in explaining the corporate cash holdings behavior. According to Ditmar et al. (2003), there are great differences in cash holdings levels between countries that have greater shareholders protection means countries that having good corporate governance than those where shareholders' protection is lower means that is the countries that have poor governance.

To examine the role of the country's legal regime and shareholder rights in this relationship, panel regressions are estimated for subsamples based on shareholder protection. Apart India, the other countries (Brazil, Russia, China, and Turkey) have a civil-law legal tradition that is deemed to provide little protection to minority investors and poor law enforcement (La Porta et al., 1998). Table 3 also highlight that firms located in common law (India) has the lowest cash ratio rather than the firms located in civil-law countries (Brazil, Russia, China and Turkey). This provides evidence that tradeoff theory exists and firms in countries with greater investor protection and better capital markets hold less cash (Opler et al. (1999) and Kim et al. (1998) 
whereas bank-oriented firms where the need of extensive and disclosure is questioned hold high cash (Dittmar 2003; Francis et al. 2013; Hall et al. 2014).

Table 5 reports the results of the panel data regressions separately for firms located in civil-law (Brazil, Russia, China, and Turkey) and common-law (India) countries.

The existence of growth opportunities and liquid asset substitutions significantly affect the cash holding decisions of nonfinancial firms for civil and common countries. While the findings state that firms in civil law countries with growth opportunities negatively affects cash levels, firms in common law countries with high growth opportunities hold high cash. For civil law countries, results seem to consistent with free cash flow theory that states that managers with poor investment opportunities (low market-to-book ratio) hold more cash to ensure availability of funds for investment in growth projects. This result suggests the agency problem is prevalent in these firms where managers try to avoid raising external funds for keeping the investment information of the company to themselves.

Firms with higher liquid assets substitutes hold high cash has been found for all the models. For both the common and civil law countries, liquid assets substitutes are found to be statistically significant in explaining the variations on cash holding. The insignificant relationship implies that leverage cannot act as a substitute of cash holdings and exert an impact on the firm's cash holding decisions. Furthermore, for common-law firms dividends pay out and firm size has been found a positive impact on cash holdings.

The findings also exhibit that different corporate governance practices can influence the cash policies of a firm. The findings show that companies with good corporate governance normally hold cash at much lower levels than companies that have poor corporate governance. Schauten et al. 2013 investigate the relation between the quality of corporate governance and the value of excess cash for large publicly listed European firms from common-law and civil-law countries. Their results confirm that in countries with the weakest legal protection of investors, benefits of a good governance structure are the highest. Aras (2015) states that country characteristics strongly influence the aspects of governance practices while predicting firm financial structure together with the view of common and civil-law differentiation for BRICK Countries.

Table 5: Fixed Effects Regression Model Results for Civil-law Countries and Common-law Countries

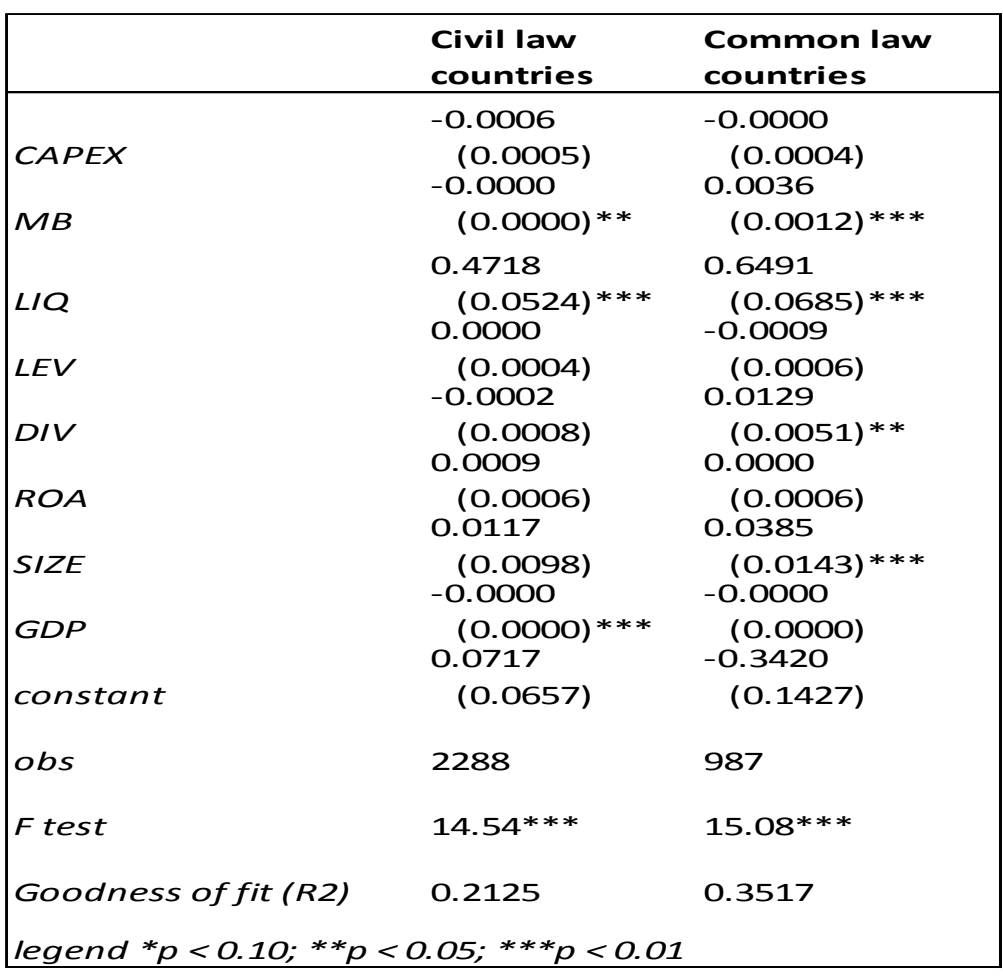




\section{CONCLUSION}

An appropriate level of cash is required within the firm for the good and smooth operations of any sort of business entity. This paper investigates the determinants of cash holding in nonfinancial firms of BRIC countries and Turkey across different firm sizes and industries. Furthermore the data set for the period of 2005 to 2014 for the capital expenditure, growth opportunities, liquid assets, leverage and dividend policy has been taken to study the impact of these on level of corporate cash holdings.

Financial determinants influence the corporate cash holdings, but it's not clear which dominant corporate cash holding theories, trade-off, financial hierarchy and agency theories, supports best the empirical findings. Panel data findings provide some strong evidence for the determinants of cash holdings. Capital expenditures are a significant determinant for cash holdings and have a negative impact on cash holdings. Dividend payout is also a significant determinant of cash holdings and has a negative impact on cash holdings. Firm size is another significant determinant of cash holding and has a positive impact on cash holdings. This is most likely explained due to the fact that larger companies have been more successful and thus should have relatively more cash, as explained by the pecking order theory.

The results of this cross-country model provide evidence that growth opportunities, liquid assets and dividend policy are significant factors in determining cash holdings in firms across these emerging countries. This paper also sheds light on the role of economic development on corporate cash holdings. Findings provide that less developed countries tend to hold more cash.

Firm cash flow has been expected in theory to relate negatively to liquid assets, as firms with higher cash flow can afford to keep lower levels of cash, resulting in a negative relation between cash flow measures and holdings of liquid assets.

A key insight of this research is that for all the models considering the civil and common law differentiation, firms with higher liquid assets hold high cash is found. This finding is considered to be indicative of the precautionary motive for cash and under financial constraint of these firms since cash has been seen a relatively safe investment.

Corporate cash holdings and its determinants have been discussed, this study also gives further explanation on the literature analyzing the relationship regarding the question of whether country's legal regime matters while determining cash holding. Findings state that countries which have poor corporate governance hold cash at higher levels compared to countries that have good corporate governance. It is also worth noticing from results for the common and civil law differentiation performed for the regression coefficients, that coefficients for growth opportunities all differ significantly in the way they affect the cash ratios of the two groups.

This study has been carried out in as robust a manner as possible to ensure that its objectives have been successfully achieved. However, it has several limitations. Among the limitations are the missing values in the data derived from database. The sample size of the study is rather small compared to other international studies. In addition, the sample period was rather limited as it covered ten years.

Despite the limitation of firm-level data and the shorter time period under investigation, these findings have significant implications for understanding the determinants of corporate cash holding in emerging countries. In addition to what that has been investigated in this research, there are several other avenues to be explored in future research regarding cash holdings, leverage and corporate governance. Such future research could incorporate ownership structure and corporate governance mechanisms as part of the variables used in governance attitudes as well as the financial constraints and cash flow sensitivity in the corporate cash holding aspect.

\section{REFERENCES}

Acharya, V., Amihud, Y., Litov, L. (2011). Creditor rights and corporate risk-taking, Journal of Financial Economics, 102, 150-166

Afza, T., Adnan, S.M. (2007). Determinants of corporate cash holdings: A Case study of Pakistan. Proceedings of Singapore Economic Review Conference, Organized by Singapore Economics Review and The University of Manchester (Brooks World Poverty Institute), $164-165$.

Al-Najjar, B., Y. Belghitar. (2011). Corporate cash holdings and dividend payments: Evidence from simultaneous analysis, Managerial and Decision Economics, Vol. 32, No. 4, pp. 231-241.

Al-Najjar, B. (2013). The financial determinants of corporate cash holdings: Evidence from some emerging markets, International Business Review, Vol. 22, No.1, pp. 77-88. 
Ali, A., Yousaf, S. (2013). Determinants of cash holding in German Market, Journal of Business and Management, ISSN: 2278-487X, p-ISSN: 2319-7668, Vol. 12, Issue 6, pp. 28- 34

Almeida, H., Campello M., Weisbach M.S. (2004). The cash flow sensitivity of cash, The Journal of Finance, 59, pp.1777-1804.

Ameer (2014). Financial constraints and corporate investment in Asian countries, Journal of Asian Economics, 33, pp.44-55.

Amess, K., Banerji, S., Lampousis, A. (2015). Corporate cash holdings: Causes and consequences, International Review of Financial Analysis, p.13

Anagnostopoulou, S. (2013). Cash holdings: Determining factors and impact on future operating performance for listed versus unlisted Firms, Review of Pacific Basin Financial Markets and Policies, Vol. 16, No. 2

Anjum, S., Q.A. Malik. (2013). Determinants of corporate liquidity - An analysis of cash holdings, Journal of Business and Management, Vol.7, No. 2, pp. 94-100.

Attig, N., El Ghoul, S. Guedhami, O. and Riseanu, S. (2013). The governance role of multiple large shareholders: Evidence on the valuation of cash holdings. Journal of Management and Governance, 17 (2) 419-451.

Aras, G. (2015). The effect of corporate governance practices on financial structure in emerging markets: Evidence from BRICK countries and lessons for Turkey, Emerging Markets Finance and Trade, 51, sup.2, pp.5-24.

Baumol, W. J. (1952). The transactions demand for cash: An inventory theoretic approach, Quarterly Journal of Economics, Vol. 66, 545-556.

Bates, T., Kahle K., Stulz R. (2009). Why Do U.S. Companies hold so much more cash than they used to? Journal of Finance, Vol. 64, No. 5, pp. 1985-2021.

Belkhir, M. Boubaker S. Derouiche I. (2014). Control-ownership wedge, board of directors, and the value of excess cash, Economic Modelling, 39(C), 110-122.

Berger, P., Ofek, E. (1995). Diversification's effect on firm value. Journal of Financial Economics, 37, 39-65.

Borhanuddin, R. Ching P. (2011). Cash Holdings, leverage, ownership concentration and board independence: Evidence from Malaysia, Malaysian Accounting Review, Vol. 10 No. 1, 63-88, 2011

Brisker, E.R. Çolak, G. Peterson, D.R. (2013). Changes in cash holdings around the S\&P 500 additions, Journal of Banking \& Finance, 37, pp. 1787-1807.

Cetenak, E.H., Vural, G. (2015). Business group affiliation and financial constraints: Investment-cash flow sensitivity of Turkish business groups, Journal of Economics, Finance and Accounting (JEFA), Vol.2, Issue 3, ISSN: 2148-6697, pp.313-330.

Chen, Y. R. (2008). Corporate governance and cash holdings: Listed new economy versus old economy firms, Corporate Governance, Vol.16, No.5, pp.430-442

Chen, S.S. Chou, R.K. Chou S. (2009). The impact of investment opportunities and free cash flow on financial liberalization: A cross-firm analysis of emerging economies, Financial Management, pp.543-566

Chen, Q., Chen X., Schipper K., Yongxin X. (2012). The Sensitivity of Corporate Cash Holdings to Corporate Governance, Working paper series

Chen, D., Li, S., Xiao, J.Z., Zou, H. (2014). The effect of government quality on corporate cash holdings. Journal of Corporate Finance, 27, pp.384-400.

Chen, X. Sun, Y. Xu, X., (2015a). Free cash flow, over-investment and corporate governance in China, Pacific-Basin Finance Journal, doi: 10.1016/j.pacfin.2015.06.003

Chen Y, Dou P.Y. Ghon R. Truong C, Veeraraghavan M. (2015b). National culture and corporate cash holdings around the World, Journal of Banking \& Finance, 50, pp. 1-18.

Daher, M. (2010). The Determinants of Cash Holdings in UK Public and Private Companies, (Thesis), Lancaster University Management School.

Dittmar, A., J. Mahrt-Smith, Servaes H. (2003). International corporate governance and corporate cash holdings", Journal of Financial and Quantitative Analysis, Vol.38, No. 1, pp. 111-133.

Egimbaeva, B. (2013). Corporate Investment and Cash Flow Sensitivity: Evidence from Turkey, Dokuz Eylul University, Master Thesis.

Ferreira, A., Vilela S. (2004). Why do companies hold cash? Evidence from EMU countries, European Financial Management, Vol. 10, No. 2, pp. 295-319

Francis, B., Iftekhar H., Liang S., Maya W. (2013). Corporate governance and investment-cash flow sensitivity: Evidence from emerging markets, Emerging Markets Review, Elsevier, vol. 15(C), pp. 57-71.

Gill, A., Shah, C. (2012). Determinants of corporate cash holdings: Evidence from Canada, International Journal of Economics and Finance, Vol.4, No.1, pp.70-79. 
Guney, Y., Ozkan, A., Ozkan, N. (2003). “Additional International Evidence on Corporate Cash Holding”. EFMA Helsinki meetings

Guney, Y., Ozkan, A., Ozkan, N. (2006). International Evidence on the non-linear impact of leverage on corporate cash holdings, Journal of Multinational Financial Management, 17(1):45-60

Hall, T. Mateus, C. Mateus, I. (2014). What determines cash holdings at privately held and publicly traded firms? Evidence from 20 emerging markets, International Review of Financial Analysis, 33, 104-116.

Harford, J. (1999). “Corporate Cash Reserves and Acquisitions” Journal of Finance, Vol.54, pp. 1969-1997

Jensen, M. and Meckling, W. (1976). Theory of the Firm: Managerial Behavior, Agency Costs and Ownership Structure, Journal of Financial Economics, Vol.3, Issue 4, pp. 305-360.

Jensen, M. (1986). Agency Costs of Free Cash Flow, Corporate Finance, and Takeovers, American Economic Review, 76, 2, pp. 323-329.

Kim, C., D.C. Mauer, A.E. Sherman. (1998). The Determinants of Corporate Liquidity: Theory and Evidence, Journal of Financial and Quantitative Analysis, Vol.33, 335-359.

Koshio, S., Sales Cia, J.N. de. (2003). The Determinants of Corporate Cash Holdings in Brazil, (Working Paper), EAESP.

Kraus, A., R.H. Litzenberger. (1973). A State-Preference Model of Optimal Financial Leverage, The Journal of Finance, Vol.28, pp. $911-922$.

Kuan, T. Li, C. Chu, S. (2011). Cash holdings and corporate governance in family-controlled firms, Journal of Business Research. Vol.64, pp. 757-764.

Kuan, T. Li, C. Liu, S. (2012). Corporate governance and cash holdings: A quantile regression approach, International Review of Economics and Finance, Vol. 24, pp.303-314.

Kusnadi, Y. Wei, K.C. (2011). The determinants of corporate cash management policies: Evidence from around the World, Journal of Corporate Finance, 17, 725-740.

La Porta, R. Lopez-de-Silanes, F. Shleifer A. Vishny R. (1998). Law and Finance, Journal of Political Economy, Vol. 106, No. 6. pp. 1113-1155.

Lee, K.W., Lee, C.F. (2009). Cash Holdings, Corporate Governance Structure and Firm Valuation, Review of Pacific Basin Financial Markets and Policies, Vol. 12, No. 3. 475-508.

Luo, M. (2011). A bright side of financial constraints in cash management, Journal of Corporate Finance, 17, pp. 1430-1444.

Masood, A. Shah, A. (2014). Corporate governance and cash holdings in listed non-financial firms in Pakistan, Business Review, Vol.9, No.2, 48-73.

Megginson, W.L., Wei, Z. (2010). Determinants and value of cash holdings: Evidence from China's privatized firms. SSRN Working Paper Series, $1-37$.

Miller, M.H., Orr, D. (1966). A Model of the Demand for Money by Companies, Quarterly Journal of Economics, Vol. 80, No.3, pp. $413-435$.

Myers, S.C., Majluf, N.S., (1984). Corporate financing and investment decisions when firm have information that investors do not have. Journal of Financial Economics, 13 (2), 187-221.

Ogundipe L.O., S.E. Ogundipe, S.K. Ajao. (2012). Cash Holding and Company Characteristics: Evidence from Nigerian Emerging Market, Journal of Business, Economics and Finance, Vol. 1, No. 2 , pp. 45-58.

Opler, T., Pinkowitz, L., Stulz, R. and Williamson, R. (1999). The determinants and implications of corporate cash holdings, Journal of Financial Economics, Vol. 52, pp.3-46

Ozkan, A., Ozkan N. (2004). Corporate cash holdings: An empirical investigation of UK companies, Journal of Banking and Finance, Vol. 28 (9), pp. 2103-2134.

Pinkowitz, L., Stulz, R., Williamson, R., (2006). Does the contribution of corporate cash holdings and dividends to firm value depend on governance? A Cross-country analysis, Journal of Finance, 61, 2725-2751.

Rajan, R.G. Zingales, L. (1995). What do we know about capital structure? Some evidence from international data, The Journal of Finance, Vol. 50, No. 5 pp. 1421-1460.

Ramirez, A., Tadesse, S. (2009). Corporate cash holdings, uncertainty avoidance, and multinationality of firms, International Business Review, $18,387-403$.

Rızwan, M.F. Javed, T. (2011). Determinants of corporate cash holdings: Evidence from Pakistani corporate sector, Economics, Management and Financial Markets, Volume 6(1), pp. 344-358,

Subramaniam, V., Tang, T. T., Yue, H., Zhou, X. (2011). Firm structure and corporate cash holdings, Journal of Corporate Finance, Vol. 17(3), pp. $759-773$ 
Uyar, A., Kuzey, C. (2014). Determinants of corporate cash holdings: evidence from the emerging market of Turkey, Applied Economics, Vol. 46, No. 9, 1035-1048.

Verduyn, S. (2013). An Empirical Analysis of the Determinants of Cash Holdings of Non-Financial Turkish Listed Companies, Dokuz Eylul University, Master Thesis.

Wooldridge, J.M. (2002). Econometric Analysis of Cross Section and Panel Data, MIT Press, Cambridge. 